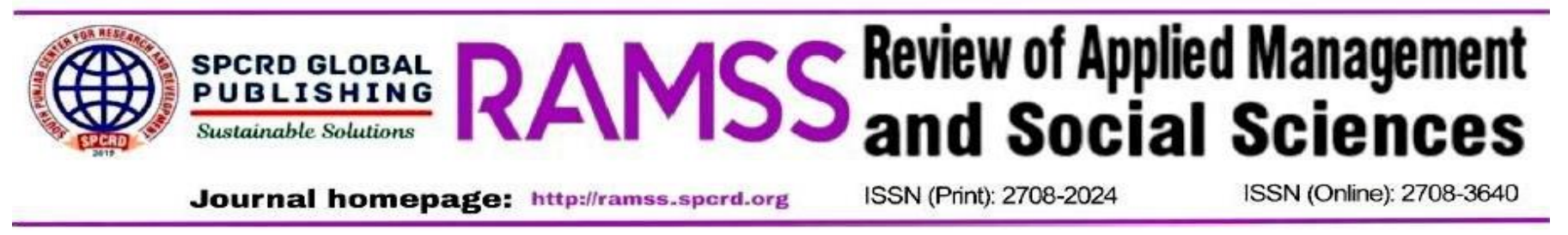

\title{
Impact of Critical Thinking Skills on Prospective Teachers' Academic Achievement
}

\author{
${ }^{\mathrm{a}}$ Ayesha Kanwal, ${ }^{\mathrm{b}}$ Intzar Hussain Butt \\ ${ }^{a}$ PhD Scholar, University of Education, Lahore, Pakistan \\ Email: Ayesha.kanwallch@gmail.com \\ ${ }^{\mathrm{b}}$ Associate Professor, University of Education, Lahore, Pakistan \\ Email: ib@ue.edu.pk
}

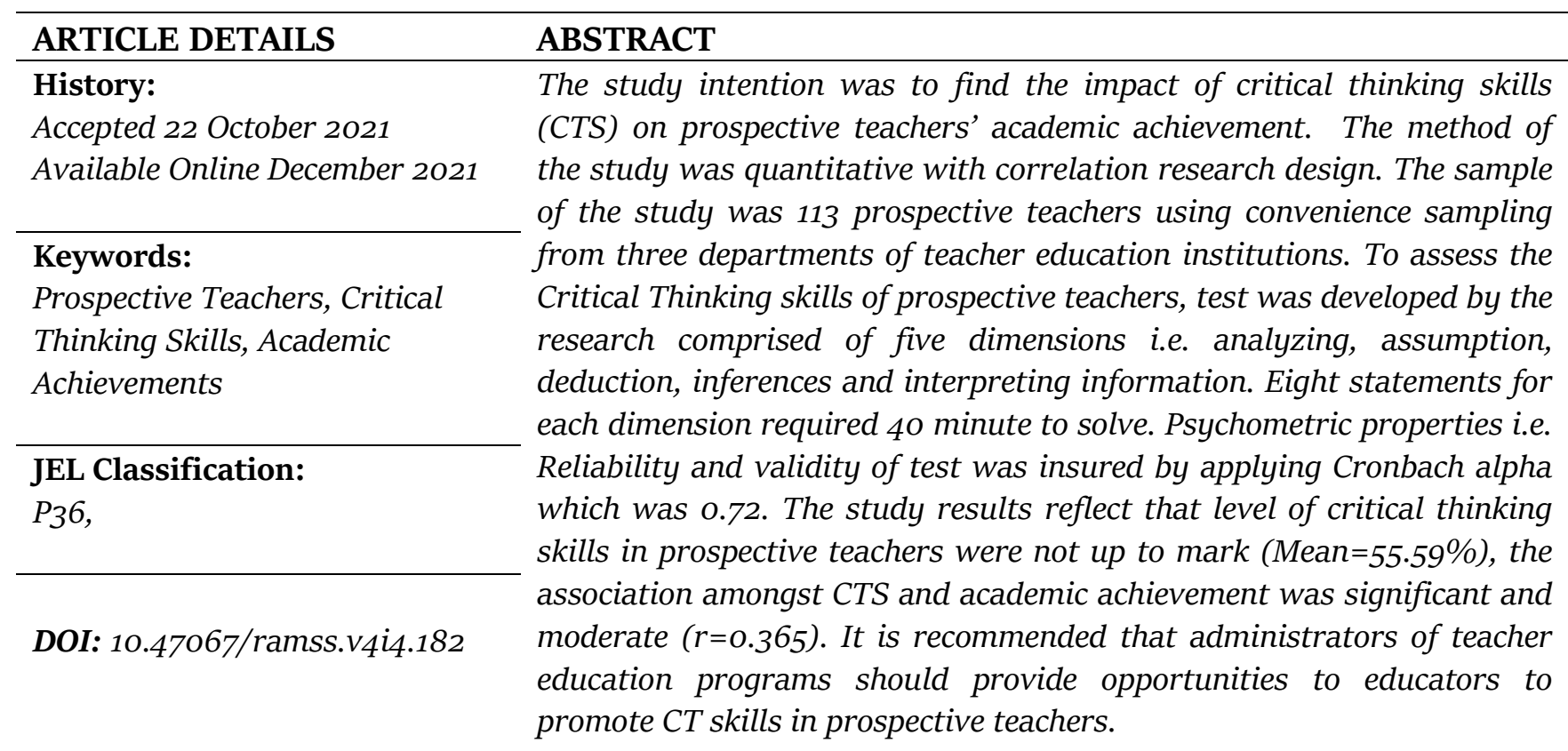

(C) 2021 The authors. Published by SPCRD Global Publishing. This is an open-access article under the Creative Commons Attribution-

NonCommercial 4.0

Corresponding author's email address: Ayesha.kanwallch@gmail.com

\section{Introduction}

The speed and amount of information is changing rapidly in the age of information and technology. Thus, rather than just memorizing current information, today's educational programs strive to train individuals who can create knowledge by going through their own cognitive filters. Individuals are required to have higher order reasoning capabilities in this situation, such as selfcontrol techniques, analytical thought, problem solving, and metacognitive thinking, among others. Critical thinking (CT) is a vital skill of these since it is used in the majority of thinking processes (Modrek et al., 2019). Critical thinking skills (CTS) have long been regarded as a primary goal of education. Students must be taught to think critically and grow in educational institutions. 
Review of Applied Management and Social Sciences (RAMSS) Vol. 4, (4) 2021,773 - 781

The beginnings of CT literature may be found in two major theoretical branches: philosophy and psychology (Lewis \&Smith, 1993). A third CT component in the sphere of education was identified by Sternberg in 1986. As a result of these disparate academic groups' varying priorities, many approaches of defining CT have evolved (Sternberg, 1986). The philosophical method is exemplified in the literatures of ancient philosopher, and, more recently, Lipman and Paul. CT can be described in a variety of ways, according to philosophical definitions: "Skillful, responsible thinking that facilitates good judgment because it relies on criteria, is self-correcting, and is sensitive to context" (McPeck, 1990) "Skillful, responsible thinking that facilitates good judgment because it relies on criteria, is self-correcting, and is sensitive to context" (McPeck, 199 ; Lipman, 1987). As one of the instructive objectives of the $21^{\text {st }}$ century's is the development of CTS. The development of CT in students has been a priority of National Educational Policies in Pakistan, National Education Policies and National Professional Standards for Teachers are examples of such policies and standards (2009).

CT is a skill that may be developed in a well-structured atmosphere. CT is not only necessary in the classroom, but it is also necessary in the workplace. Workers that can solve problems and think critically are in high demand in today's economy and technological complexity. This is why CT is a component of various intellectual works, thoughts, and advances in the sphere of education (Siegel, 1988; McPeck, 1990; Facione, 1990; Swartz, 1994 Ennis, 1997; Halpern, 1998; Fisher, 2001; Elder, 2005). In addition to those thinkers, many others who focused on CTS, dispositions, have decided that forfeiting greater, an important tendency in education is to pay attention to students' and instructors' active states (Eggen \& Kauchak, 2001; Slavin, 2006; Gralewski \& Karwowski, 2012; Cottrell, 2017).

It is eminent that academics and educators all throughout the realm agree that CTS are important to students' academic achievement. Academic achievement is a word that describes progress toward defined educational goals and is considered one of the most important measures of a student's talents and knowledge. Academic achievement is frequently connected to a student's particular skills and abilities. As evidenced by a student's school performance, i.e., a learner who, while enrolled in a civic or reserved school system, at appropriate age, successfully completes a high school certificate or alike, with no interruptions or failures (Rodriguez ,2007). "What is the effect of CT on our academic achievement?" is the question that needs to be answered now. There are several factors that have an impact on a student's academic achievement; CT is one of the most significant aspects in academic achievement. Learners who use CT develop a variety of skills and competences that help them be more productive. As a consequence, this element contributes to the students' success (Taghva, et al., 2014). Several studies, the majority of which were conducted at the institution level, have found a substantial link amongst CT and academic accomplishment as rated by CGPA (Garett \& Wulf, 1978; Steward \& Al-Abdulla, 1989; Cabrera, 1992; Williams, et al., 2003; Williams \& Stockdale, 2003). This is why the researcher attempted to investigate prospective teacher's CTS. The researcher evaluated the existence of CTS, the level of prospective teachers CTS, using data from three divisions of the teacher education institute to investigate the association between CTS and academic achievement of prospective teachers. This study's findings are likely to aid in the formation of future teachers, educational curricula, and academic achievements in this area. 
The objectives of the study were to

1. Find the level of critical thinking skills of prospective teachers Lahore, Pakistan.

2. Determine the correlation amongst CTS and academic achievement of prospective teachers.

3. Measure which component of critical thinking skills more correlated with academic achievement.

The research question of the study is:

- What is the level of critical thinking skills of prospective teachers?

\section{Research Hypothesis}

$\mathbf{H}_{\mathbf{o}} \mathbf{1}$ : There was no significant relationship amongst CTS and academic achievement of prospective teachers.

$\mathbf{H}_{\mathbf{o}}$ 2: There was no predictor among components of critical thinking skills which explains variation in academic achievement.

\section{Methodology}

The following methodology was used to conduct this study.

\subsection{Design}

The study's objectives were met by a quantitative technique. The study design was correlational and survey was conducted to determine the correlation amongst CTS and academic achievement of prospective teachers.

\subsection{Population}

The study population was prospective teachers in public sector Teacher education Institutes of Lahore, Punjab. Pakistan.

\subsection{Sampling and sample size}

Teacher training Institute $\mathrm{X}$ is oldest and biggest institute of teacher education in Lahore. There are 10 departments and two centers working for teacher education. Three departments Department-A, Department-B, Department-C were selected through convenience sampling. The sample of study was 113, approximately 37 prospective teachers from each department.

\subsection{Measures and data collection}

To assess the CTS of prospective teachers, researcher developed test were used. The test was consisted of five components i.e. analyzing arguments, assumptions, deduction, inference and interpreting information. Total number of statements in test was 40 and for each skill eight statements were developed. The reliability estimated by Cronbach Alpha was .72. Time to solve the test was 40 minutes. 
Review of Applied Management and Social Sciences (RAMSS) Vol. 4, (4) 2021,773 - 781

\section{Data analysis}

Table 1: Demographic information of participants

\begin{tabular}{|c|l|l|}
\hline Variables & $\mathrm{n}$ & $\%$ \\
\hline Gender & & \\
\hline Male & 15 & 13.3 \\
\hline Female & 98 & 86.7 \\
\hline Age (years) & & \\
\hline $18-20$ & $18-20$ & 56 \\
\hline $21-22$ & $21-23$ & 57 \\
\hline Resident & & \\
\hline Village & 20 & 17.7 \\
\hline City & 93 & 82.3 \\
\hline
\end{tabular}

Table 1 displays demographic information of participants. There are 15(13.3\%) male prospective teachers and 98(86.7\%) female prospective teachers. The age of prospective teachers fall between 18 years to 22 years. Majority of prospective teachers reside in cities and one fifth lives in village area.

Table 2: Summary statistics of study variables

\begin{tabular}{|l|l|l|l|l|l|l|}
\hline & $\begin{array}{l}\text { Potential } \\
\text { Range }\end{array}$ & $\begin{array}{l}\text { Actual } \\
\text { Range }\end{array}$ & $\mathrm{M}(\mathrm{SD})$ & $95 \%$ CI & $\begin{array}{l}\text { Skewness } \\
(\mathrm{SE})\end{array}$ & Kurtosis (SE) \\
\hline CGPA & $\mathrm{O}-4$ & $2.38-3.81$ & $3.34(0.25)$ & $3.30-3.39$ & $-0.58(.227)$ & $1.02(.451)$ \\
\hline Analyzing & $\mathrm{o}-100$ & $12.5-100$ & $63.96(16.33)$ & $60.91-67.00$ & $0.34(.227)$ & $-0.34(.451)$ \\
\hline Assumptions & $\mathrm{o}-100$ & $12.5-100$ & $53.87(18.98)$ & $50.33-57.41$ & $0.30(.227)$ & $-0.32(.451)$ \\
\hline Deduction & $\mathrm{o}-100$ & $12.5-100$ & $59 \cdot 30(18.84)$ & $55.79-62.81$ & $-0.08(.227)$ & $-0.18(.451)$ \\
\hline Inference & $\mathrm{o}-100$ & $25.0-100$ & $41.35(17.98)$ & $37.99-44.70$ & $0.53(.227)$ & $-0.14(.451)$ \\
\hline Interpreting & $\mathrm{o}-100$ & $37.0-97.5$ & $59.49(16.88)$ & $56.34-62.50$ & $0.16(.227)$ & $-0.43(.451)$ \\
\hline Total CTS & $\mathrm{o}-100$ & $35.0-100$ & $55.59(11.38)$ & $53.47-57.71$ & $0.97(.227)$ & $\mathrm{o} .91(.451)$ \\
\hline
\end{tabular}

Table 2 shows summary statistics of study variables i.e. academic achievement, analyzing, assumptions, deduction, inference, interpreting. Mean score of analyzing, assumptions, deduction, interpreting prospective teacher's skill was above normal. The Mean score of inference prospective teacher's skill was below normal. The overall mean score CTS of prospective teachers was close to average. Because the values of skewness range from -0.58 to 0.97 and the values of kurtosis range from -0.14 to 0.91 , the distribution of data for all study variables shows the normal allocation. 
Review of Applied Management and Social Sciences (RAMSS) Vol. 4, (4) 2021,773 - 781

Figure 1: Mean Scores of critical thinking skills

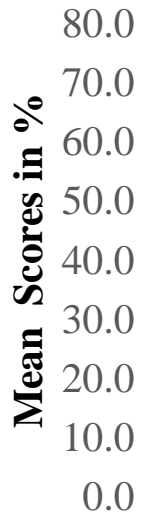

Critical Thinking skills of Propective Teachers

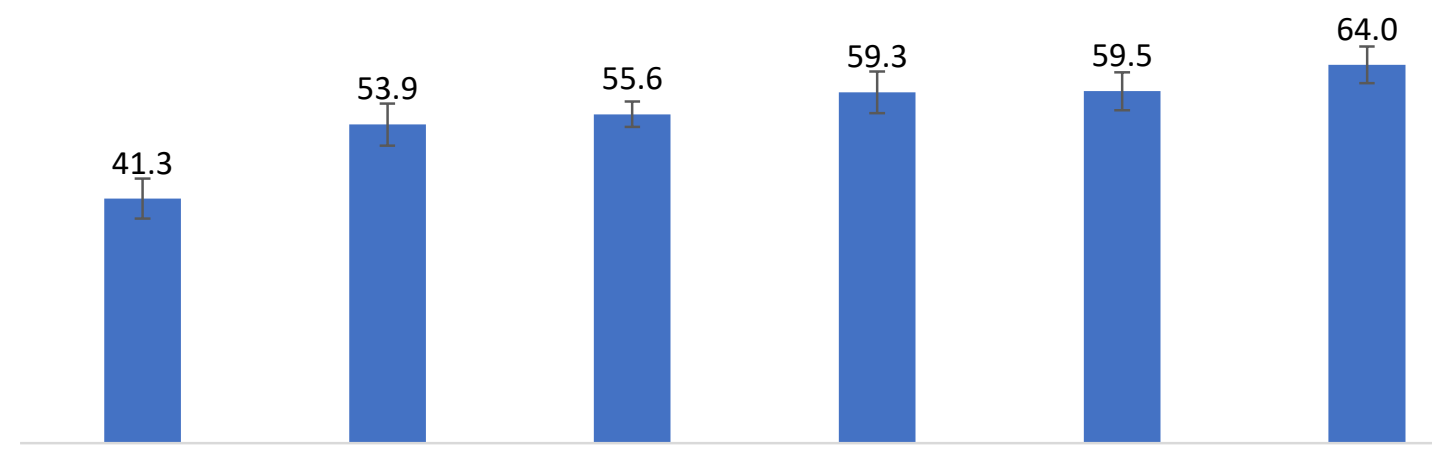

Inference Assumptions Total CTS Deduction Interpreting Analyzing

Dimentions of Critical Thinking Skills

Note. Mean scores of critical thinking skills of prospective teachers of public sector university Lahore, Pakistan

Table 3: Criteria for level of critical thinking skills

\begin{tabular}{|l|l|}
\hline Scores & Levels of critical thinking skills \\
\hline $80-100$ & At Excellent level \\
\hline $60-80$ & At Good level \\
\hline $40-60$ & At Fair level \\
\hline $20-40$ & At Poor level \\
\hline $0-20$ & At Very Poor level \\
\hline
\end{tabular}

Table 3 shows criteria for level of five dimensions CTS. The score of each student was calculated using following formula.

$$
\text { Student score }=\frac{\text { Obtained Score }}{\text { Total Scores }} * 100 \%
$$

Table 4: Levels of critical thinking skills

\begin{tabular}{|l|l|l|l|l|l|l|}
\hline Scores & Analyzing & Assumptions & Deduction & Inference & Interpreting & Total CTS \\
\hline $80-100$ & $15 \%$ & $8 \%$ & $11 \%$ & $1 \%$ & $12 \%$ & $4 \%$ \\
\hline $60-80$ & $52 \%$ & $35 \%$ & $42 \%$ & $20 \%$ & $44 \%$ & $27 \%$ \\
\hline $40-60$ & $23 \%$ & $22 \%$ & $27 \%$ & $20 \%$ & $27 \%$ & $67 \%$ \\
\hline $20-40$ & $10 \%$ & $33 \%$ & $18 \%$ & $52 \%$ & $18 \%$ & $3 \%$ \\
\hline 0-20 & $0 \%$ & $2 \%$ & $3 \%$ & $7 \%$ & $12 \%$ & $0 \%$ \\
\hline
\end{tabular}

Table 4 shows different levels of CTS of prospective teachers. It can be observed from the table that in Analyzing skill 52\% prospective teachers fall in good level, while in assumptions 35\%, in deduction $42 \%$, interpreting information $44 \%$ prospective teachers also fall in good level. In inference the level of CTS of prospective teachers was poor. The overall CTS, $67 \%$ of prospective teachers fall in Fair level. 
Review of Applied Management and Social Sciences (RAMSS) Vol. 4, (4) 2021,773 - 781

Figure 2: Levels of critical thinking skills

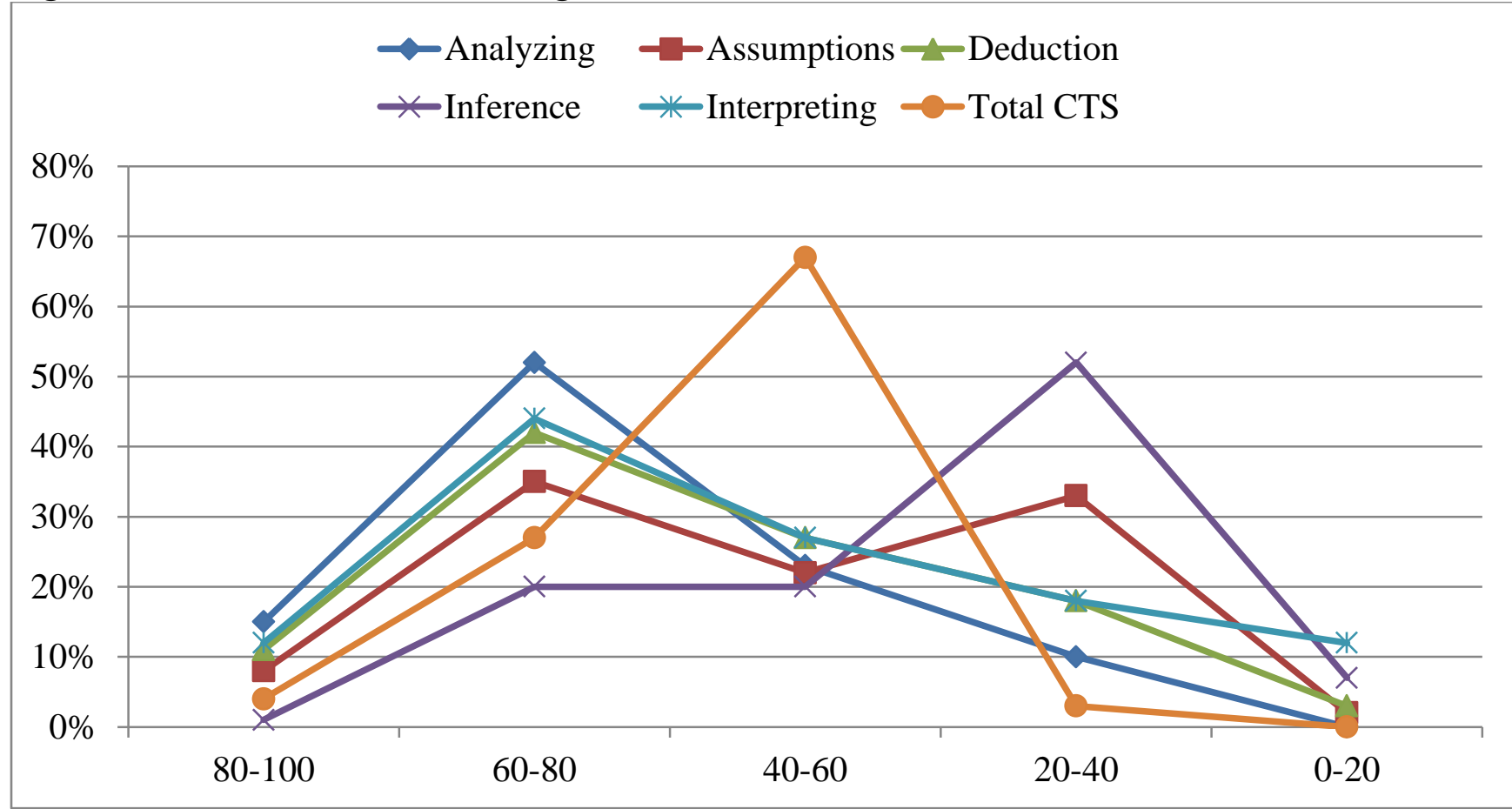

Note. Levels of critical thinking skills of prospective teachers of public sector teacher education institute of Lahore, Pakistan

Table 5: Pearson coefficient of correlation between critical thinking and academic achievement

\begin{tabular}{|l|l|l|l|l|l|l|l|}
\hline & CGPA & Analyzing & Assumptions & Deduction & Inference & Interpreting & Total CTS \\
\hline CGPA & - & & & & & & \\
\hline Analyzing & $.194^{*}$ & - & & & & & \\
\hline Assumptions & $.190^{*}$ & $.474^{* *}$ & - & & & & \\
\hline Deduction & $.262^{* *}$ & .134 & $.224^{*}$ & - & & & \\
\hline Inference & $.320^{* *}$ & .124 & $.254^{* *}$ & $.35^{* *}$ & - & & \\
\hline Interpreting & $.194^{*}$ & $.246^{* *}$ & $.201^{*}$ & $.364^{* *}$ & $.218^{*}$ & - & \\
\hline Total CTS & $.365^{* *}$ & $.601^{* *}$ & $.684^{* *}$ & $.663^{* *}$ & $.617^{* *}$ & $.624^{* *}$ & - \\
\hline
\end{tabular}

Note. ${ }^{*} \mathrm{p}<.05,{ }^{*} \mathrm{p}<.01$, Weak $=0-0.19$, Moderate $=.20-.49$, Strong $=.50$ to 1.00 (Pallant, 2013)

The relation between CT and academic achievement is seen in Table 3. To identify a linkage between CT and academic achievement, the Pearson coefficient of correlation was applied. Academic achievement and analyzing, assumptions, and interpreting skills had a poor link (ro.2) as per Pearson coefficient of correlation results. The Pearson coefficient of correlation also revealed a moderate link ( $\mathrm{r}=0.2$ to 0.49 ) between academic achievement and deduction, inference, and overall CTS. 
Review of Applied Management and Social Sciences (RAMSS) Vol. 4, (4) 2021,773- 781

Table 6: Summary of Regression Analysis: academic achievement is dependent variable and analyzing, assumptions, deduction, inference, interpreting as predictor

\begin{tabular}{|l|l|l|l|l|l|}
\hline & $\mathrm{B}$ & $\mathrm{SE}$ & $\beta$ & $\mathrm{t}$ & Sig. \\
\hline Constant & 2.904 & .119 & & 24.340 & $<.001$ \\
\hline Analyzing & .002 & .002 & .117 & 1.134 & .259 \\
\hline Assumptions & .000 & .001 & .033 & .315 & .753 \\
\hline Deduction & .002 & .001 & .135 & 1.337 & .184 \\
\hline Inference & .003 & .001 & .237 & 2.435 & $.017^{*}$ \\
\hline Interpreting & .001 & .001 & .058 & .593 & .555 \\
\hline
\end{tabular}

Note. ${ }^{*} \mathrm{p}<.05$

Table 4 shows summary of regression analysis. Academic achievement is dependent variable and analyzing, assumptions, deduction, inference, interpreting as predictor of academic achievement. Multiple regressions were conducted to find the best predictor of academic achievement. Results of regression analysis reveal inference skill $(\beta=.237, p=.017)$ has noteworthy result on academic achievement, while other skills i.e. analyzing, assumptions, deduction, and interpreting have no noteworthy outcome on academic achievement ( $p>.05)$.

\section{Discussion}

The need of CTS is getting popularity among psychologists and educationist due to its relationship with school and job performance. Individuals are required to have higher order reasoning capabilities in this situation, such as self-control techniques, analytical thought, problem solving, and metacognitive thinking, among others. CT is a vital skill of these since it is used in the majority of thinking processes (Modrek, et al., 2019). Therefore, this study has importance in determining the level of CTS among prospective teachers and finding the best predictor of CT component for academic achievement. In other words, students with better level of critical thinking skills have higher abilities of analyzing information, making assumptions, deduction, inference and interpretation of experiences. As a result, such students have better academic achievements (Fathi et al., 2007). The study included both females and males' prospective teachers of age from 18 to 22 years belong to city and village area. The results of the study are limited to given characteristics of the sample. Mean score of overall CTS in prospective teachers were 55.59 out of 100 which is close to average score. At dimension level mean score of inference were below average and mean scores of analyzing was above average which is supported by the findings of Shahzadi and Khan (2020).

CTS and academic achievement were reported to have significant moderate related in this study. Inference was highest $(\mathrm{r}=.320, \mathrm{p}<.01)$ and making assumptions was lowest $(\mathrm{r}=.190, \mathrm{p}<0.5)$ correlation with academic achievement. The findings of this section of our research are similar to those of Shaabani (2003), and Taghva et al. (2014). According to Shaabani (2003), there is a noteworthy correspondence amongst CT and academic achievement. Taghva et al. (2014) found noteworthy correlation between CTS and academic achievement. In this regard, many studies supported noteworthy correlation between CTS and academic achievement (Vierra, 2014; Ross et al., 2013; Fong et al., 2017; Ghanizadeh, 2017). Further which CT skill is predictor of academic achievement? Results show that Inference $(\beta=.237, p=.017)$ is predictor of academic achievement. 
Review of Applied Management and Social Sciences (RAMSS) Vol. 4, (4) 2021,773 - 781

\section{Conclusion}

Current education policy demands high level of critical thinking skills of students. It is only possible when teachers are aware and equipped with high level of CTS. The study exposes present level of critical thinking skills of prospective teachers which is not up to mark. There is need to incorporate CTS in curriculum, teaching strategies and assessment in teaching learning process. Without infusing CTS in curriculum, it is not possible the meet the objective of $21^{\text {st }}$ century educational goals.

\section{Recommendations}

It is recommended that further research should be conducted on textbooks to explore how much CTS $\mathrm{t}$ is present in content and practices during instructions. Studies should be conducted on educators to find attitude toward CTS.

\section{References}

Cabrera, G. A. (1992). A framework for evaluating the teaching of critical thinking. Education, 113(1), 59-63.

Cottrell, S. (2017). Critical thinking skills: Effective analysis, argument and reflection. Macmillan International Higher Education.

Eggen, P., \& Kauchak, D. (2011). Strategies and models for teachers: Teaching content and thinking skills. Pearson Higher Ed.

Elder, L. (2005). Critical thinking as the key to the learning college: A professional development model. New Directions for Community Colleges, 2005(130), 39-48.

Ennis, R. (1997). Incorporating critical thinking in the curriculum: An introduction to some basic issues. Inquiry: Critical Thinking across the disciplines, 16(3), 1-9.

Facione, P. A. (1990). The California Critical Thinking Skills Test--College Level. Technical Report\# 1. Experimental Validation and Content Validity.

Fathi-Ashtiani, A., Ejei, J., Khodapanahi, M. K., \& Tarkhorani, H. (2007). Relationship between selfconcept, self-esteem, anxiety, depression and academic achievement in adolescents. Journal of Applied Sciences, 7(7), 955-1000.

Fisher, A. (2011). Critical thinking: An introduction. Cambridge university press.

Fong, C. J., Kim, Y., Davis, C. W., Hoang, T., \& Kim, Y. W. (2017). A meta-analysis on critical thinking and community college student achievement. Thinking Skills and Creativity, 26, 71- 83 .

Garett, K., \& Wulf, K. (1978). Relationship of a measure of critical thinking ability to personality variables and to indicators of academic achievement. Educational \& Psychological Measurement, 38, 1181-1187

Ghanizadeh, A. (2017). The interplay between reflective thinking, critical thinking, self- monitoring, and academic achievement in higher education. Higher Education, 74(1), 101- 114.

Government of Pakistan. (2009). National professional standards for teachers in Pakistan.. Islamabad, Pakistan: Policy and Planning Wing, Ministry of Education.

Gralewski, J., \& Karwowski, M. (2012). Polite girls and creative boys? Students' gender moderates the accuracy of teachers' ratings of creativity. The Journal of Creative Behavior, 47(4), 290304 .

Halpern, D. F. (1998). Teaching critical thinking for transfer across domains: Disposition, skills, structure training, and metacognitive monitoring. American psychologist, 53(4), 449.

Lewis, A., \& Smith, D. (1993). Defining higher order thinking. Theory into Practice, 32(3),131-137

Lipman, M. (1987). Critical thinking: What can it be?. Analytic Teaching, 8(1).

McPeck, J. E. (1990). Critical thinking and subject specificity: A reply to Ennis. Educational 
Review of Applied Management and Social Sciences (RAMSS) Vol. 4, (4) 2021,773- 781

researcher, 19(4), 10-12.

Modrek, A. S., Kuhn, D., Conway, A., \& Arvidsson, T. S. (2019). Cognitive regulation, not behavior regulation, predicts learning. Learning and Instruction, 6o, 237-244.

Pallant, J. (2013). SPSS survival manual. McGraw-hill education (UK)

Rodriguez, C. (2007). Self-Efficacy Beliefs, Faculty Expectations, and Institutional Climate As Determinants of Academic Achievement In Business Students. Journal of Business \& Leadership: Research, Practice, and Teaching (2005-2012), 3(1), 1-13.

Ross, D., Loeffler, K., Schipper, S., Vandermeer, B., \& Allan, G. M. (2013). Do scores on three commonly used measures of critical thinking correlate with academic success of health professions trainees? A systematic review and meta-analysis. Academic Medicine, 88(5), 724734 .

Shaabani, V. B., (2003). The effects of three training approaches, primary schools students' conference and its role in the society, Isfahan, Iran.

Shahzadi, U., \& Khan, I. (2020). Exploring the Relationship between Critical Thinking Skills and Academic Achievement. sjesr, 3(1), 236-242

Siegel, H. (1988). Rationality and epistemic dependence. Educational Philosophy and Theory, 20(1), 1-6.

Slavin, R. E., \& Davis, N. (2006). Educational psychology: Theory and practice. 2003. View Link.

Sternberg, R. J. (1986). Critical Thinking: Its Nature, Measurement, and Improvement.

Steward, R. J., \& Al-Abdulla, Y. (1989). An examination of the relationship between critical thinking and academic success on a university campus.

Swartz, R. J., \& Parks, S. (1994). Infusing the Teaching of Critical and Creative Thinking into Content Instruction: A Lesson Design Handbook for the Elementary Grades. Critical Thinking Press and Software, PO Box 448, Pacific Grove, CA 93950-0448.

Taghva, F., Rezaei, N., Ghaderi, J., \& Taghva, R. (2014). Studying the relationship between critical thinking skills and students' educational achievement (eghlid universities as case study). International Letters of Social and Humanistic Sciences, 25, 18-25

Taghva, F., Rezaei, N., Ghaderi, J., \& Taghva, R. (2014). Studying the relationship between critical thinking skills and students' educational achievement (eghlid universities as case study). International Letters of Social and Humanistic Sciences, 25, 18-25.

Vierra, R. W. (2014). Critical thinking: Assessing the relationship with academic achievement and demographic factors (Doctoral dissertation, University of Minnesota).

Williams, R. L., \& Stockdale, S. L. (2003). High-performing students with low critical thinking skills. The Journal of General Education, 200-226.

Williams, R. L., Oliver, R., Allin, J. L., Winn, B., \& Booher, C. S. (2003). Psychological critical thinking as a course predictor and outcome variable. Teaching of Psychology, 30(3), 220-223. 